\title{
Epigenetic profiling of synchronous colorectal neoplasias by quantitative DNA methylation analysis
}

\author{
Shuji Ogino ${ }^{1,2,3}$, Mohan Brahmandam², Takako Kawasaki², Gregory J Kirkner ${ }^{4}$, \\ Massimo Loda ${ }^{1,2,3}$ and Charles S Fuchs ${ }^{2,3,4}$ \\ ${ }^{1}$ Department of Pathology, Brigham and Women's Hospital, Boston, MA, USA; ${ }^{2}$ Department of Medical \\ Oncology, Dana-Farber Cancer Institute, Boston, MA, USA; ${ }^{3}$ Departments of Pathology and Medicine, \\ Harvard Medical School, Boston, MA, USA and ${ }^{4}$ Department of Medicine, Brigham and Women's \\ Hospital, Boston, MA, USA
}

\begin{abstract}
Transcriptional inactivation of tumor-suppressor genes by promoter $\mathrm{CpG}$ island methylation is thought to be an important mechanism in human carcinogenesis. The CpG island methylator phenotype (CIMP) with extensive promoter methylation appears to be a distinct epigenetic subtype of colorectal carcinoma. Most previous studies on CpG island methylation in colorectal carcinoma used methylation-specific PCR, which may detect low levels of DNA methylation with little or no biological significance. In contrast, quantitative DNA methylation assays have been shown to provide useful information beyond that which can be achieved with methylationspecific PCR. Synchronous neoplasias provide a unique model for investigators to examine molecular alterations in multistep tumorigenesis within one individual. However, no study to date has quantified DNA methylation of CIMP-specific promoters in synchronous colorectal neoplasias. Utilizing real-time PCR (MethyLight), we quantified DNA methylation in five CIMP-specific gene promoters [CACNA1G (calcium channel, voltage-dependent, T type alpha-1G subunit), CDKN2A (p16/INK4A), CRABP1 (cellular retinoic acid binding protein-1), MLH1 and NEUROG1 (neurogenin 1)] and MGMT in six synchronous carcinoma pairs (12 carcinomas) and eight synchronous carcinoma and adenoma pairs (16 tumors). We found that while some synchronous tumor pairs showed discordant promoter methylation patterns, other tumor pairs showed similar, but not exactly identical, patterns of promoter methylation. All but two pairs showed concordant patterns of CIMP status (CIMP positive vs CIMP negative) $(P=0.05$ in cancer pairs). $B R A F$ mutations were present in only CIMP-positive tumors. A high degree of microsatellite instability (MSI-H) was observed in both CIMP-positive and CIMP-negative tumors. KRAS mutations were not concordant in any synchronous neoplasia pair. In conclusion, epigenetic alterations at CIMP-specific promoter $\mathrm{CpG}$ islands in synchronous colorectal neoplasias likely have both random and nonrandom components.
\end{abstract}

Modern Pathology (2006) 19, 1083-1090. doi:10.1038/modpathol.3800618; published online 12 May 2006

Keywords: colon cancer; adenoma; epigenetics; methyLight; hypermethylation; CIMP

Transcriptional inactivation of tumor-suppressor genes by promoter $\mathrm{CpG}$ island methylation is thought to be an important mechanism in human carcinogenesis. ${ }^{1}$ A number of tumor-suppressor genes, such as CDKN2A (p16/INK4A), MGMT, and $M L H 1$, have been shown to be silenced by promoter methylation in colorectal carcinoma. ${ }^{2}$ In fact, a subset of colorectal carcinomas have been shown

Correspondence: Dr S Ogino, MD, PhD, Department of Pathology, Brigham and Women's Hospital, Harvard Medical School, 75 Francis St., Boston, MA 02115, USA.

E-mail: shuji_ogino@dfci.harvard.edu

Received 7 February 2006; revised 21 March 2006; accepted 31

March 2006; published online 12 May 2006 to exhibit promoter methylation in multiple genes, which is referred to as the $\mathrm{CpG}$ island methylator phenotype (CIMP)., ${ }^{3,4}$ CIMP-positive colorectal cancers have a distinct clinical, pathologic, and molecular profile, such as associations with proximal tumor location, female sex, mucinous and poor tumor differentiation, microsatellite instability (MSI), and high BRAF and low TP53 mutation rates. ${ }^{4-8}$

Methylation-specific PCR, which has been widely used in previous studies, provides only binary qualitative (ie, present vs absent) results without information of the degree of DNA methylation. Owing to this technical limitation, methylationspecific PCR cannot reliably distinguish high from low levels of methylation with little or no biological 
significance. By quantitative DNA methylation analysis, we have shown that most colorectal cancers with a low level of methylation in the MLH1, MGMT or CDKN2A (p16) promoters do not silence protein expression. ${ }^{9}$ As a result, a variety of quantitative DNA methylation assays have been developed, such as real-time PCR-based assays (MethyLight). ${ }^{10-12}$ Using MethyLight, we have previously quantified methylation of five carefully selected gene promoters [CAGNA1G (calcium channel, voltage-dependent, $\mathrm{T}$ type alpha-1G subunit) CDKN2A, CRABP1 (cellular retinoic acid binding protein 1), MLH1 and NEUROG1 (neurogenin 1)] in 460 colorectal carcinomas, and shown a clear bimodal distribution of 80 microsatellite instabilityhigh (MSI-H) tumors according to the number of methylated loci. ${ }^{8}$ Considering that most previous studies using methylation-specific PCR failed to demonstrate such a clear bimodal distributions of the number of methylated promoters, ${ }^{3,5-7}$ our data indicated that CIMP be best characterized by quantitative DNA methylation analysis and CIMPspecific gene promoters. ${ }^{8}$

Synchronous neoplasias in the same organ system within the same individual can provide a unique model for investigators to examine development of neoplasias through multistep carcinogenesis. These synchronous neoplasias have arisen due to very similar or the same etiologic factors, whether genetic or environmental. Previous studies have shown that synchronous colorectal neoplasias frequently have discordant molecular abnormalities, confirming that these synchronous tumors indeed have independent clonal origins. ${ }^{13-15}$ There are previous studies that have examined MLH1 promoter methylation by methylation-specific PCR in synchronous colorectal cancers. ${ }^{16-18}$ However, no study to date has examined CpG island methylation of multiple promoters in synchronous colorectal neoplasias by quantitative DNA methylation analysis. We hypothesized that synchronous colorectal neoplasias can develop due to a nonrandom promoter $\mathrm{CpG}$ island methylation with background of similar or the same etiologic factors. In this study, we have quantified DNA methylation of multiple promoter $\mathrm{CpG}$ islands in synchronous colorectal tumor pairs (carcinoma/ carcinoma and adenoma/carcinoma pairs), in order to evaluate whether there are nonrandom DNA methylation patterns.

\section{Materials and methods}

\section{Study Group}

In order to recruit patients into this study, we utilized the database of two large prospective cohort studies; the Nurses' Health Study $(N=121700$ women), and the Health Professionals Follow-up Study $(N=51500$ men $) .{ }^{19}$ Informed consent was obtained from all participants prior to inclusion in the cohort studies. All study participants were free of cancer (with the exception of nonmelanoma skin cancer) at the study entry. A subset of study participants reported the incidence of colorectal cancer through response to questionnaires. We selected patients who had two synchronous colorectal neoplasias with at least one carcinoma. Patients were excluded from this study if adequate paraffinembedded tumor tissue was not available for pathologic and molecular analysis. As a result, we identified and analyzed a total of six synchronous colorectal carcinoma pairs (12 carcinomas) from six patients and eight synchronous colorectal carcinoma and adenoma pairs (16 tumors) from eight patients. We reviewed pathology reports and recorded the location, the size, and the TNM stage of each tumor. Information of $\mathrm{M}$ stage was also obtained by medical record review. A family history (with either 0,1 or $\geq 2$ first-degree relatives affected with colorectal cancer) was obtained through questionnaire. Tissue collection and analyses were approved by the Dana-Farber Cancer Institute and Brigham and Women's Hospital Institutional Review Boards.

\section{Pathologic Evaluation and Genomic DNA Extraction}

Hematoxylin and eosin (H\&E) stained tissue sections of all tumors were examined under a light microscope. Degree of tumor differentiation was evaluated according to previously published criteria. ${ }^{20}$ After pathologic review of the H\&E stained slides for each case, areas composed entirely of tumor were circled on the coverslip with a felt pen to guide subsequent tumor dissection. Tumor tissue was dissected manually from additional tissue sections by a sterile needle. Normal colonic tissue was obtained from the margins of the resection specimens. The dissected tissue was placed in buffered proteinase $\mathrm{K}$ solution at $56^{\circ} \mathrm{C}$ for $3 \mathrm{~h}$. Genomic DNA was extracted using QIAmp DNA Mini Kit (Qiagen, Valencia, CA, USA), according to the manufacturer's instructions.

\section{Real-Time PCR (MethyLight) for Quantitative DNA Methylation Analysis}

Sodium bisulfite treatment on genomic DNA was performed as described. ${ }^{9}$ Real-time PCR to measure DNA methylation (MethyLight) was performed as previously described..$^{10-12}$ We used ABI 7300 (Applied Biosystems, Foster City, CA, USA) for quantitative real-time PCR. Briefly, using seven sets of primers and probe, we amplified promoters of the six genes of interest (CACNA1G, CDKN2A (p16) INK4A), CRABP1, MLH1, NEUROG1 and MGMT). COL2A1 (the collagen 2A1 gene) was used to normalize for the amount of input bisulfite-converted DNA. ${ }^{9,12}$ Primers and probes were previously described as follows: CDKN2A, MGMT and COL2A1; ${ }^{12}$ CACNA1G, CRABP1 and NEUROG1; ${ }^{8}$ and MLH1. ${ }^{9}$ The percentage of methylated reference (PMR ie degree of methylation) at a specific locus was 
calculated by dividing the GENE:COL2A1 ratio of a sample by the GENE:COL2A1 ratio of M. SsSI-treated human genomic DNA (presumably fully methylated) and multiplying by $100 .{ }^{21}$ The PMR cutoff of 4 was previously validated. ${ }^{8-12,21,22}$ Furthermore, we have shown that methylation positivity in CDKN2A and MLH1 determined by the PMR cutoff of 4 was highly correlated with loss of respective protein expression $\left(P<10^{-16}\right){ }^{9}$ Precision and performance characteristics of bisulfite conversion and subsequent MethyLight assays have been previously evaluated and the assays have been validated. ${ }^{9}$ All of the six genes showed frequent promoter hypermethylation in cancerous tissue, and infrequent, low levels of methylation in normal colonic mucosa.

The CIMP was defined as the presence of $\geq 4$ methylated promoters among five gene promoters including CACNA1G, CDKN2A, CRABP1, MLH1 and NEUROG1. ${ }^{8}$ All of the five promoters showed high sensitivity ( $>90 \%$ ) and/or specificity ( $>90 \%$ ) for the prediction of CIMP status. ${ }^{8}$ MGMT was not included in the CIMP panel because of its low sensitivity $(\sim 62 \%)$ and specificity $(\sim 66 \%)$ for the prediction of overall CIMP status. ${ }^{8}$

\section{MSI Analysis}

For MSI analysis, whole genome amplification of genomic DNA was performed by PCR using random 15-mer primers. ${ }^{23}$ Methods to determine MSI status have previously been described. ${ }^{24}$ In addition to the recommended MSI panel consisting of D2S123, D5S346, D17S250, BAT25 and BAT26, ${ }^{25}$ we also used BAT40, D18S55, D18S56, D18S67 and D18S487 (ie, 10-marker panel). ${ }^{24}$ All microsatellite analyses except for D2S123, D5S346 and D17S250 were performed in duplicate. A 'high degree of MSI' (MSI-H) was defined as the presence of instability in $\geq 30 \%$ of the markers. A low degree of MSI (MSI-L) was defined as the presence of instability in $<30 \%$ of the markers, and 'microsatellite stable (MSS)' tumors were defined as tumors with no unstable marker.

\section{KRAS and BRAF Sequencing}

Methods of PCR and sequencing targeted for KRAS codons 12 and 13, and $B R A F$ codon 600 have been previously described.$^{26}$ All forward sequencing results were confirmed by reverse sequencing. KRAS sequencing was validated by Pyrosequencing technology as previously described. ${ }^{23}$

\section{Results}

We analyzed a total of 12 synchronous colorectal carcinomas from six patients and and eight synchronous carcinoma-adenoma pairs (16 tumors) from eight patients. Clinical and pathologic features of these synchronous tumors were listed in Tables 1 and 2. All of the synchronous tumors were grossly separate lesions although some synchronous tumors were located in the same anatomic location in one individual (Case 1, $11 \mathrm{~cm}$ apart in ascending colon; Case 4, $5 \mathrm{~cm}$ apart in ascending colon; Case 13, $3 \mathrm{~cm}$ apart in sigmoid colon; Cases 7, 8 and 14, precise distances between two synchronous lesions unknown). There were no serrated adenomas analyzed, in the study group. We quantified methylation of six gene promoters of interest (CACNA1G, CDKN2A, CRABP1, MLH1, NEUROG1 and MGMT). We have previously shown that promoter methylation in each of the first five gene promoters (CACNA1G, $C D K N 2 A, C R A B P 1, M L H 1$ and NEUROG1) is highly predictive for CIMP. ${ }^{8}$ We also sequenced the KRAS and $B R A F$ genes, and determined MSI status of the synchronous tumors.

Quantitative DNA methylation analysis revealed similar patterns of promoter methylation between two synchronous carcinomas in most cases (Table 1). For instance, high degrees of promoter methylation were observed in five genes in both of two cancers from Case 1, with only MGMT showing a discordant pattern of methylation. Likewise, cancer pairs from Case 3 and Case 6 showed similar patterns of methylation in MGMT; a cancer pair from Case 5 also showed a similar pattern of methylation in CDKN2A, CRABP1 and MGMT. On the other hand, a cancer pair from Case 4 showed a similar pattern of DNA methylation in CRABP1, but not in CACNA1G, CDKN2A and NEUROG1. A cancer pair from Case 2 showed a completely discordant pattern of DNA methylation with one tumor showing methylation in all six promoters and the other showing no methylation in any of the six promoters. Except for Case 2, all of the other pairs showed concordant patterns of overall CIMP status (a CIMP-positive pair in Case 1, and non-CIMP pairs in Cases 3 through 6). Based on the overall frequency of CIMP in colorectal cancer by our previous study $(17 \%=78 / 460),{ }^{8}$ a statistical significance level of finding these concordant CIMP status patterns is $P=0.05\left(=(0.17)^{2} \times 2(0.17)(1-0.17) \times\right.$ $\left.\left((1-0.17)^{2}\right)^{4} \times(6 ! /(1 ! \times 1 ! \times 4 !))\right)$. All CIMP-positive carcinomas (two from Case 1 and one from Case 2) exhibited five methylated CIMP-panel promoters, high degree of MSI (MSI-H) and BRAF mutations. KRAS mutations were not concordant in any of the pairs when at least one of the two cancers had a KRAS mutation.

Quantitative DNA methylation analysis also revealed similar patterns of promoter methylation in some pairs of synchronous colorectal carcinoma and adenoma (Table 2). For instance, a tumor pair from Case 7 showed high degrees of methylation in MGMT and low levels of methylation in CDKN2A; a tumor pair from Case 11 showed methylation in only CRABP1; and a tumor pair from Case 12 showed methylation in MGMT and CRABP1 (very low levels). Tumor pairs from Case 8, Case 13 and 
Table 1 Epigenetic and genetic alterations in synchronous colorectal carcinomas

\begin{tabular}{|c|c|c|c|c|c|c|c|c|c|c|c|c|c|c|c|}
\hline \multirow{2}{*}{$\begin{array}{l}\text { Case } \\
\text { No. }\end{array}$} & \multirow{2}{*}{$\begin{array}{l}\text { Age } \\
\text { sex }\end{array}$} & \multirow{2}{*}{$\begin{array}{l}\text { Family } \\
\text { history }^{a}\end{array}$} & \multirow{2}{*}{ Diagnosis } & \multirow{2}{*}{$\begin{array}{l}\text { Size } \\
(\mathrm{cm})\end{array}$} & \multirow{2}{*}{$\begin{array}{l}\text { Tumor } \\
\text { location }\end{array}$} & \multicolumn{6}{|c|}{ PMR (degree of promoter methylation) ${ }^{\mathrm{b}}$} & \multirow{2}{*}{$K R A S^{d}$} & \multirow{2}{*}{$\begin{array}{l}\text { BRAF } \\
\text { codon } \\
600^{e}\end{array}$} & \multirow{2}{*}{ MSI } & \multirow{2}{*}{ TNM stage and other notes } \\
\hline & & & & & & CACNA1G & CDKN2A & CRABP1 & MLH1 & NEUROG 1 & $M G M T^{\mathrm{C}}$ & & & & \\
\hline 1 & $68 \mathrm{~F}$ & No & $\begin{array}{l}\text { WDC } \\
\text { MDC }\end{array}$ & $\begin{array}{l}5.5 \\
2.8\end{array}$ & $\begin{array}{l}A \\
A\end{array}$ & $\begin{array}{l}504.20 \\
176.00\end{array}$ & $\begin{array}{l}345.30 \\
218.40\end{array}$ & $\begin{array}{c}113.07 \\
85.60\end{array}$ & $\begin{array}{l}81.16 \\
33.00\end{array}$ & $\begin{array}{c}159.53 \\
46.40\end{array}$ & $\begin{array}{c}0 \\
87.60\end{array}$ & $\begin{array}{l}\text { WT } \\
\text { WT }\end{array}$ & $\begin{array}{l}\text { gag } \\
\text { gag }\end{array}$ & $\begin{array}{l}\mathrm{H} \\
\mathrm{H}\end{array}$ & $\begin{array}{l}\text { T3NOMO } \\
\text { T3NOMO }\end{array}$ \\
\hline \multirow[t]{2}{*}{2} & \multirow{2}{*}{$71 \mathrm{~F}$} & \multirow{2}{*}{$\begin{array}{l}1 \text { first } \\
\text { degree } \\
\text { relative }\end{array}$} & WDC & - & A & 190.43 & 46.86 & 43.36 & 19.73 & 56.23 & 36.37 & WT & gag & $\mathrm{H}$ & \multirow{2}{*}{$\begin{array}{l}\text { TxNxMO. } 9 \text { other } \\
\text { synchronous adenomas; } 2 \\
\text { with intramucosal ca. }\end{array}$} \\
\hline & & & WDC & - & $\mathrm{R}$ & 0 & 0 & 0 & 0 & 0 & 0 & WT & WT & s & \\
\hline 3 & $60 \mathrm{~F}$ & $\begin{array}{l}1 \text { first } \\
\text { degree } \\
\text { relative }\end{array}$ & MDC & - & A & 0 & 0 & 31.70 & 0 & 0 & 71.90 & $12 \mathrm{gct}$ & WT & s & T3NOMx \\
\hline 4 & $65 \mathrm{~F}$ & No & $\begin{array}{l}\text { MDC } \\
\text { WDC }\end{array}$ & $\begin{array}{l}5.0 \\
2.0\end{array}$ & $\begin{array}{l}A \\
A\end{array}$ & $\begin{array}{c}308.56 \\
0.04\end{array}$ & $\begin{array}{c}0 \\
1.58\end{array}$ & $\begin{array}{l}43.10 \\
38.91\end{array}$ & $\begin{array}{l}0 \\
0\end{array}$ & $\begin{array}{c}17.03 \\
0\end{array}$ & $\begin{array}{l}0 \\
0\end{array}$ & - & - & - & $\begin{array}{l}\text { T3NOMO } \\
\text { T2NOMO }\end{array}$ \\
\hline 5 & $79 \mathrm{M}$ & No & $\begin{array}{l}\text { MDC } \\
\text { MDC }\end{array}$ & $\begin{array}{l}5.0 \\
2.0\end{array}$ & $\begin{array}{c}\text { RS } \\
\text { R }\end{array}$ & $\begin{array}{c}0.04 \\
0\end{array}$ & $\begin{array}{c}93.25 \\
202.24\end{array}$ & $\begin{array}{l}7.62 \\
3.22\end{array}$ & $\begin{array}{c}0 \\
0.55\end{array}$ & $\begin{array}{l}0 \\
0\end{array}$ & $\begin{array}{l}36.37 \\
33.69\end{array}$ & $\begin{array}{c}12 \mathrm{gtt} \\
13 \mathrm{gac}\end{array}$ & $\begin{array}{l}\text { WT } \\
\text { WT }\end{array}$ & $\begin{array}{l}S \\
S\end{array}$ & $\begin{array}{l}\text { T3NOMx } \\
\text { T2NOMx }\end{array}$ \\
\hline 6 & $66 \mathrm{M}$ & No & $\begin{array}{l}\text { WDC } \\
\text { WDC }\end{array}$ & $\begin{array}{l}4.5 \\
0.6\end{array}$ & $\begin{array}{c}\text { A } \\
\text { Sig }\end{array}$ & $\begin{array}{l}0 \\
0\end{array}$ & $\begin{array}{l}0 \\
0\end{array}$ & $\begin{array}{c}0 \\
0.06\end{array}$ & $\begin{array}{l}0 \\
0\end{array}$ & $\begin{array}{l}0 \\
0\end{array}$ & $\begin{array}{l}38.94 \\
77.26\end{array}$ & $\begin{array}{l}\text { WT } \\
\text { 12gat }\end{array}$ & $\begin{array}{l}\text { WT } \\
\text { WT }\end{array}$ & $\begin{array}{l}S \\
S\end{array}$ & $\begin{array}{l}\text { T3NOM1 } \\
\text { T2NOM1 }\end{array}$ \\
\hline
\end{tabular}

${ }^{\mathrm{a}}$ The presence of colorectal cancer in any first-degree relative.

${ }^{\mathrm{b}}$ Grey shading indicates PMR $>4$ (positive for significant methylation).

${ }^{\mathrm{c}}$ Note that MGMT was not included in the CIMP promoter panel.

$\mathrm{d}$ KRAS mutations are described as the codon number, followed by mutated codon. Wild-type codon 12 is GGT and wild-type codon 13 is GGC.

e $B R A F$ mutations are described as mutated codon 600. Wild-type codon 600 is GTG.

Abbreviations: A, ascending colon including cecum; H, MSI-high; MDC, moderately differentiated carcinoma; MSI, microsatellite instability;

PDC, poorly differentiated carcinoma; R, rectum; RS, rectosigmoid colon; S, microsatellite stable; Sig, sigmoid colon; WDC, well-differentiated

carcinoma; WT, wild-type. 
Table 2 Epigenetic and genetic alterations in synchronous colorectal carcinoma and adenoma pairs

\begin{tabular}{|c|c|c|c|c|c|c|c|c|c|c|c|c|c|c|c|}
\hline \multirow{2}{*}{$\begin{array}{l}\text { Case } \\
\text { No. }\end{array}$} & \multirow{2}{*}{$\begin{array}{l}\text { Age } \\
\text { sex }\end{array}$} & \multirow{2}{*}{ Family history $^{a}$} & \multirow{2}{*}{ Diagnosis } & \multirow{2}{*}{$\begin{array}{l}\text { Size } \\
(\mathrm{cm})\end{array}$} & \multirow{2}{*}{$\begin{array}{l}\text { Tumor } \\
\text { location }\end{array}$} & \multicolumn{6}{|c|}{ PMR (degree of promoter methylation) ${ }^{b}$} & \multirow{2}{*}{$K R A S^{d}$} & \multirow{2}{*}{$\begin{array}{c}\text { BRAF } \\
\text { codon } \\
600^{\mathrm{e}}\end{array}$} & \multirow{2}{*}{ MSI } & \multirow{2}{*}{$\begin{array}{l}\text { TNM stage and } \\
\text { other notes }\end{array}$} \\
\hline & & & & & & CACNA1G & $C D K N 2 A$ & $C R A B P 1$ & $M L H 1$ & NEUROG1 & $M G M T^{\mathrm{C}}$ & & & & \\
\hline 7 & $73 \mathrm{~F}$ & No & $\begin{array}{c}\text { MDC } \\
\text { TA }\end{array}$ & $\begin{array}{l}1.4 \\
0.5\end{array}$ & $\begin{array}{l}\text { Sig } \\
\text { Sig }\end{array}$ & $\begin{array}{l}0 \\
0\end{array}$ & $\begin{array}{l}0.19 \\
0.38\end{array}$ & $\begin{array}{c}0 \\
1.17\end{array}$ & $\begin{array}{l}0 \\
0\end{array}$ & $\begin{array}{c}0 \\
0.21\end{array}$ & $\begin{array}{c}5.30 \\
30.55\end{array}$ & $\begin{array}{l}\text { 12gat } \\
\text { WT }\end{array}$ & $\begin{array}{l}\text { WT } \\
\text { WT }\end{array}$ & $\begin{array}{l}\mathrm{H} \\
\mathrm{S}\end{array}$ & T1N1M0 \\
\hline 8 & $70 \mathrm{~F}$ & No & $\begin{array}{l}\text { WDC } \\
\text { TA }\end{array}$ & $\begin{array}{l}4.0 \\
0.8\end{array}$ & $\begin{array}{l}A \\
A\end{array}$ & $\begin{array}{l}0 \\
0\end{array}$ & $\begin{array}{c}0.04 \\
0\end{array}$ & $\begin{array}{l}0.06 \\
1.22\end{array}$ & $\begin{array}{l}0 \\
0\end{array}$ & $\begin{array}{l}0 \\
0\end{array}$ & $\begin{array}{c}73.81 \\
0\end{array}$ & $\begin{array}{l}12 \mathrm{gct} \\
12 \mathrm{gtt}\end{array}$ & $\begin{array}{l}\text { WT } \\
\text { WT }\end{array}$ & $\mathrm{L}$ & T1N0M0 \\
\hline \multirow[t]{2}{*}{9} & \multirow[t]{2}{*}{$72 \mathrm{~F}$} & \multirow[t]{2}{*}{ No } & PDC & - & A & 0 & 0 & 0 & 0 & 0 & 0 & WT & WT & $\mathrm{L}$ & \multirow[t]{2}{*}{$\begin{array}{l}\text { T4N1M1. Signet } \\
\text { ring cell carcinoma }\end{array}$} \\
\hline & & & TVA & 2.0 & $\mathrm{R}$ & 0 & 0 & 34.54 & 0 & 0 & 230.07 & WT & WT & $S$ & \\
\hline 10 & $69 \mathrm{~F}$ & $\begin{array}{l}1 \text { first degree } \\
\text { relative }\end{array}$ & $\begin{array}{l}\text { WDC } \\
\text { TA }\end{array}$ & $\begin{array}{l}1.5 \\
1.6\end{array}$ & $\begin{array}{c}\text { A } \\
\text { Sig }\end{array}$ & $\begin{array}{c}240.78 \\
0\end{array}$ & $\begin{array}{c}145.14 \\
0\end{array}$ & $\begin{array}{c}100.76 \\
0\end{array}$ & $\begin{array}{c}42.58 \\
0\end{array}$ & $\begin{array}{c}65.89 \\
0\end{array}$ & $\begin{array}{c}0 \\
27.39\end{array}$ & $\begin{array}{l}\text { WT } \\
12 \mathrm{gtt}\end{array}$ & $\begin{array}{l}\text { gag } \\
\text { WT }\end{array}$ & $\begin{array}{l}\mathrm{H} \\
\mathrm{S}\end{array}$ & T1N0M0 \\
\hline 11 & $60 \mathrm{~F}$ & $\begin{array}{l}\geq 2 \text { first degree } \\
\quad \text { relatives }\end{array}$ & $\begin{array}{c}\text { MDC } \\
\text { TA }\end{array}$ & $\begin{array}{l}1.2 \\
2.3\end{array}$ & $\begin{array}{l}\mathrm{A} \\
\mathrm{T}\end{array}$ & $\begin{array}{l}0 \\
0\end{array}$ & $\begin{array}{l}0 \\
0\end{array}$ & $\begin{array}{c}102.80 \\
0.49\end{array}$ & $\begin{array}{l}0 \\
0\end{array}$ & $\begin{array}{l}0 \\
0\end{array}$ & $\begin{array}{l}0 \\
0\end{array}$ & $\begin{array}{l}\text { WT } \\
\text { WT }\end{array}$ & $\begin{array}{l}\text { WT } \\
\text { WT }\end{array}$ & $\begin{array}{l}\mathrm{H} \\
\mathrm{H}\end{array}$ & T1N0M0 \\
\hline 12 & $67 \mathrm{~F}$ & No & $\begin{array}{l}\text { WDC } \\
\text { TA }\end{array}$ & $\begin{array}{l}2.5 \\
0.5\end{array}$ & $\begin{array}{l}\mathrm{D} \\
\mathrm{A}\end{array}$ & $\begin{array}{l}0 \\
0\end{array}$ & $\begin{array}{l}0 \\
0\end{array}$ & $\begin{array}{l}0.01 \\
0.12\end{array}$ & $\begin{array}{l}0 \\
0\end{array}$ & $\begin{array}{c}0.02 \\
0\end{array}$ & $\begin{array}{c}30.88 \\
2.55\end{array}$ & $\begin{array}{c}\text { 12gat } \\
\text { WT }\end{array}$ & $\begin{array}{l}\text { WT } \\
\text { WT }\end{array}$ & $\begin{array}{l}S \\
S\end{array}$ & T3NOMO \\
\hline 13 & $71 \mathrm{~F}$ & No & $\begin{array}{c}\text { MDC } \\
\text { TA }\end{array}$ & $\begin{array}{l}5.6 \\
0.7\end{array}$ & $\begin{array}{l}\text { Sig } \\
\text { Sig }\end{array}$ & $\begin{array}{l}0 \\
0\end{array}$ & $\begin{array}{c}312.42 \\
0\end{array}$ & $\begin{array}{c}0 \\
19.37\end{array}$ & $\begin{array}{l}0 \\
0\end{array}$ & $\begin{array}{l}0 \\
0\end{array}$ & $\begin{array}{l}97.84 \\
47.09\end{array}$ & $\begin{array}{c}13 \mathrm{gac} \\
\text { WT }\end{array}$ & $\overline{\text { WT }}$ & $\begin{array}{l}S \\
S\end{array}$ & T3NOMO \\
\hline 14 & $\begin{array}{l}68 \\
M\end{array}$ & No & $\begin{array}{l}\text { WDC } \\
\text { TVA }\end{array}$ & $\begin{array}{l}- \\
-\end{array}$ & $\begin{array}{l}A \\
A\end{array}$ & $\begin{array}{l}0 \\
0\end{array}$ & $\begin{array}{c}0.03 \\
0\end{array}$ & $\begin{array}{l}0.97 \\
0.90\end{array}$ & $\begin{array}{l}0 \\
0\end{array}$ & $\begin{array}{l}0 \\
0\end{array}$ & $\begin{array}{c}0 \\
180.41\end{array}$ & $\begin{array}{l}\text { 13gac } \\
12 \mathrm{gat}\end{array}$ & $\begin{array}{l}\text { WT } \\
\text { WT }\end{array}$ & $\begin{array}{l}\mathrm{H} \\
\mathrm{S}\end{array}$ & TxNxMx \\
\hline
\end{tabular}

${ }_{b}^{a}$ The presence of colorectal cancer in any first-degree relative.

${ }^{\mathrm{b}}$ Grey shading indicates PMR $>4$ (positive for significant methylation).

${ }^{\mathrm{c}}$ Note that MGMT was not included in the CIMP promoter panel.

${ }^{\mathrm{d}}$ KRAS mutations are described as the codon number,followed by mutated codon. Wild-type codon 12 is GGT and wild-type codon 13 is GGC.

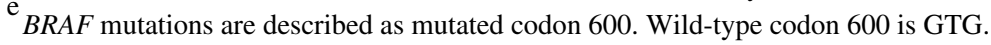

Abbreviations: A, ascending colon including cecum; D, descending colon; H, MSI-high; L, MSI-low; MDC, moderately differentiated carcinoma;

MSI, micro satellite instability; PDC, poorly differentiated carcinoma; R, rectum; RS, rectosigmoid colon; S, microsatellite stable; Sig, sigmoid

colon; T, transverse colon; TA, tubular adenoma; TVA, tubulovillous adenoma; WDC, well-differentiated carcinoma; WT, wild-type. 
Case 14 showed somewhat concordant and discordant patterns of DNA methylation. On the other hand, tumor pairs from Case 9 and Case 10 showed discordant patterns of promoter methylation. Only one carcinoma from Case 10 was CIMP positive (5/5 methylated CIMP-panel promoters) with MSI-H phenotype and BRAF mutation. Except for this Case 10, all of the other pairs showed concordant patterns of overall CIMP status as non-CIMP. All of the other MSI-H tumors in the carcinoma-adenoma pairs, including carcinomas of Case 7, Case 11 and Case 14 and adenoma of Case 11, were non-CIMP with wild-type BRAF. KRAS mutations were not concordant in any of the pairs when at least one of the two tumors had a KRAS mutation. Although detailed family history could not be obtained, Case 11 might be a case of hereditary nonpolyposis colorectal cancer (HNPCC) given $\geq 2$ affected firstdegree relatives and synchronous MSI-H carcinoma and adenoma with no MLH1 methylation.

\section{Discussion}

The purpose of this study was to examine whether patterns of epigenetic alterations at specific promoter CpG islands are nonrandom in synchronous colorectal neoplasias. Synchronous neoplasias in single individuals present a unique model for investigators to evaluate the process of cancer development. Utilizing quantitative DNA methylation analysis on a panel of 5 CIMP-specific, markers (CACNA1G, CDKN2A, CRABP1, MLH1 and NEUROG1) and MGMT, we found that some synchronous tumor pairs showed similar, but not exactly identical, patterns of promoter methylation; thus, promoter methylation in synchronous colorectal neoplasias appears to have both random and nonrandom components. In addition, overall CIMP status in synchronous colorectal cancers was significantly concordant $(P=0.05)$. Each of the five makers (CACNA1G, CDKN2A, CRABP1, MLH1 and NEUROG1) have been previously shown to be a sensitive and specific marker for the prediction of overall CIMP status, ${ }^{8}$ and hence, methylation of these markers likely reflects overall methylation status of CIMP-specific promoter CpG islands in the human genome. Therefore, our results suggest that at least some epigenetic alterations at specific promoter regions in synchronous neoplasias are likely nonrandom.

Using a panel of the five CIMP-specific markers (CACNA1G, CDKN2A, CRABP1, MLH1 and NEUROG1), we have previously demonstrated a clear bimodal distribution of MSI-H tumors according to the number of methylated markers; ${ }^{8}$ all $80 \mathrm{MSI}-\mathrm{H}$ tumors showed either $\geq 4 / 5$ methylated promoters (CIMP positive) or $\leq 2 / 5$ methylated promoters (CIMP negative or non-CIMP) with no tumor showing 3/5 methylated promoters. ${ }^{8}$ In addition, MGMT was included in this study because of its functional significance; promoter methylation and silencing of MGMT has been associated with $\mathrm{G}>\mathrm{A}$ mutations in KRAS and TP53, ${ }^{27,28}$ and its promoter methylation in normal colonic mucosa may be significant as a field effect (or field defect) in colorectal cancer development. ${ }^{29,30}$

Our study utilized quantitative real-time PCR (MethyLight) to measure DNA methylation. In contrast to our quantitative method, methylationspecific PCR-based assays have been widely used to determine promoter methylation in multiple genes and to determine CIMP status., ${ }^{3,5-7,31,32}$ However, methylation-specific PCR cannot reliably distinguish high from low levels of DNA methylation, the latter of which has been shown to be little or no biological significance. ${ }^{9}$ In fact, we have previously shown that most colorectal cancers that show low levels of methylation (PMR $<4$ by MethyLight) in the CDKN2A (p16), MLH1 and MGMT promoters do not silence protein expression. ${ }^{9}$ Thus, we feel that studies that have evaluated CIMP status by nonquantitative methylation-specific PCR assays should be evaluated with caution.

Several previous studies have examined promoter CpG island methylation in synchronous colorectal neoplasias with at least one carcinoma. Chan et $\mathrm{al}^{33}$ examined DNA methylation of four loci (CDKN2A, MLH1, MINT1, MINT2 and MINT31) in synchronous or metachronous colorectal cancer and hyperplastic polyps (with or without serrated/nonserrated adenomas) from nine individuals. The authors found overall concordant patterns of CIMP status in synchronous tumors in cases with predominance of hyperplastic polyps in the right colon or cases with serrated adenomas. Chan et $a l^{33}$ used methylation-specific PCR, and detailed patterns of DNA methylation in each locus were not shown. Norrie et $a{ }^{17}$ examined MSI status, methylation and expression of MLH1 in 33 synchronous colorectal cancers in 14 individuals, and found that only one patient showed methylation in all synchronous tumors, whereas five patients showed discordant methylation status among their synchronous tumors. The authors concluded that synchronous tumors arised as independent events and that the slightly greater frequency of synchronous tumors in individuals with MSI-H cancers was likely to be a chance event reflecting the older age of these individuals rather than arising from a predisposition to promoter hypermethylation in colorectal epithelium. ${ }^{17}$ Norrie et $a l^{17}$ analyzed methylation in only one marker (MLH1) by methylation-specific PCR. The role of predisposition to promoter hypermethylation needs to be investigated more comprehensively using a carefully selected panel of methylation markers. Dykes et $a l^{18}$ examined MSI status and $M L H 1$ methylation and expression in a total of 170 synchronous colorectal cancers from 77 patients, and found that there was a strong concordance of MSI status among synchronous tumors. Dykes et al ${ }^{18}$ analyzed only one marker (MLH1) by methylation- 
specific PCR, and did not report concordance of MLH1 methylation. Lawes et $a 1^{16}$ examined $M L H 1$ methylation in five pairs of synchronous or metachronous colorectal cancers, and showed concordant MLH1 methylation in only one metachronous tumor pair and discordant MLH1 methylation in two metachronous tumor pairs. Lawes et $a l^{16}$ analyzed only one marker (MLH1) by methylation-specific PCR, and only tested pairs in which at least one tumor was a MSI-H tumor with loss of MLH1 expression. Frigola et $a l^{34}$ analyzed six promoters (MLH1, APC, CDKN2A (p16), p14, MGMT, and $L K B 1$ ) in 11 synchronous adenoma-carcinoma pairs, and stated, 'the methylation profile was not always coincident in the adenoma-carcinoma pairs (data not shown), suggesting the basic role of stochastic components behind the occurrence and clonal expansion of these alterations.' Frigola et $a l^{34}$ used methylation-specific PCR assays and their detailed data were not shown.

This study is the first to quantify DNA methylation of a carefully selected CIMP-specific promoters in synchronous colorectal neoplasias. While there were some synchronous tumor pairs that showed discordant promoter methylation patterns, other synchronous tumor pairs showed similar promoter methylation patterns, suggesting that epigenetic alterations in synchronous colorectal neoplasias likely have both random and nonrandom components. Our study is limited by a small number of study subjects, and a study using a larger number of patients is necessary to better elucidate a role of DNA methylation in the development of synchronous colorectal neoplasias.

In summary, we have shown that epigenetic alterations in synchronous colorectal tumor pairs likely have both random and nonrandom components. The predisposition to DNA methylation in specific promoter $\mathrm{CpG}$ islands may play a role in the development of synchronous colorectal neoplasias. Finally, our data indicate that quantitative DNA methylation analysis is a valuable method of determining $\mathrm{CpG}$ island methylation status in colorectal carcinoma and adenoma.

\section{Note added in proofs}

The non-random promoter methylation pattern may result from 'field effect' of DNA methylation in normal or preneoplastic mucosa, which may predispose to the development of colorectal neoplasias. ${ }^{29,30}$

\section{Acknowledgements}

This work was supported by National Institute of Health (NIH) Grants P01 CA87969-03 and P01 CA55075-13. We deeply thank the Nurses' Health Study and Health Professionals Follow-up Study cohort participants who have generously agreed to provide us with biological specimens and information through responses to questionnaires. We thank Graham Colditz, Walter Willett, and many other staff members who implemented and have maintained the cohort studies. We thank Peter W Laird, Daniel Weisenberger and Mihaela Campan for their assistance in the development of the MethyLight assays. We thank Mami Cantor, Akiyo Ogawa and Inga Dorfman for technical assistance.

\section{Conflicts of interest}

No conflicts of interest in connection with this work are present.

\section{References}

1 Laird PW. Cancer epigenetics. Hum Mol Genet 2005; 14(Spec no 1):R65-R76.

2 Kondo Y, Issa JP. Epigenetic changes in colorectal cancer. Cancer Metast Rev 2004;23:29-39.

3 Toyota M, Ahuja N, Ohe-Toyota M, et al. CpG island methylator phenotype in colorectal cancer. Proc Natl Acad Sci USA 1999;96:8681-8686.

4 Toyota M, Ohe-Toyota M, Ahuja N, et al. Distinct genetic profiles in colorectal tumors with or without the CpG island methylator phenotype. Proc Natl Acad Sci USA 2000;97:710-715.

5 van Rijnsoever M, Grieu F, Elsaleh H, et al. Characterisation of colorectal cancers showing hypermethylation at multiple CpG islands. Gut 2002;51:797-802.

6 Hawkins N, Norrie M, Cheong K, et al. CpG island methylation in sporadic colorectal cancers and its relationship to microsatellite instability. Gastroenterology 2002;122:1376-1387.

7 Samowitz W, Albertsen H, Herrick J, et al. Evaluation of a large, population-based sample supports a CpG island methylator phenotype in colon cancer. Gastroenterology 2005;129:837-845.

8 Ogino S, Cantor M, Kawasaki T, et al. CpG island methylator phenotype (CIMP) of colorectal cancer is best characterized by quantitative DNA methylation analysis and prospective cohort studies. Gut 2006: In press (published online first on January 112006 : doi:10.1136/gut.2005.082933).

9 Ogino S, Kawasaki T, Brahmandam M, et al. Precision and performance characteristics of sodium bisulfite conversion and real-time PCR (MethyLight) for quantitative DNA methylation analysis. J Mol Diagn 2006;8: 209-217.

10 Eads CA, Danenberg KD, Kawakami K, et al. CpG island hypermethylation in human colorectal tumors is not associated with DNA methyltransferase overexpression. Cancer Res 1999;59:2302-2306.

11 Eads CA, Danenberg KD, Kawakami K, et al. MethyLight: a high-throughput assay to measure DNA methylation. Nucleic Acids Res 2000;28:E32.

12 Widschwendter M, Siegmund KD, Muller HM, et al. Association of breast cancer DNA methylation profiles with hormone receptor status and response to tamoxifen. Cancer Res 2004;64:3807-3813.

13 Zauber P, Sabbath-Solitare M, Marotta SP, et al. Molecular changes in the Ki-ras and APC genes in 
primary colorectal carcinoma and synchronous metastases compared with the findings in accompanying adenomas. Mol Pathol 2003;56:137-140.

14 Koness RJ, King TC, Schechter S, et al. Synchronous colon carcinomas: molecular-genetic evidence for multicentricity. Ann Surg Oncol 1996;3:136-143.

15 Eguchi K, Yao T, Konomoto T, et al. Discordance of p53 mutations of synchronous colorectal carcinomas. Mod Pathol 2000;13:131-139.

16 Lawes DA, Pearson T, Sengupta S, et al. The role of MLH1, MSH2 and MSH6 in the development of multiple colorectal cancers. Br J Cancer 2005;93:472-477.

17 Norrie MW, Hawkins NJ, Todd AV, et al. The role of hMLH1 methylation in the development of synchronous sporadic colorectal carcinomas. Dis Colon Rectum 2002;45:674-680.

18 Dykes SL, Qui H, Rothenberger DA, et al. Evidence of a preferred molecular pathway in patients with synchronous colorectal cancer. Cancer 2003;98:48-54.

19 Fuchs CS, Willett WC, Colditz GA, et al. The influence of folate and multivitamin use on the familial risk of colon cancer in women. Cancer Epidemiol Biomarkers Prev 2002;11:227-234.

20 Hamilton SR, Vogelstein B, Kudo S, et al. Carcinoma of the colon and rectum. Pathology and genetics of tumours of the digestive system. In: Aaltonen LA, Hamilton SR (eds). World Health Organization Classification of Tumours. IARC Press: Lyon, 2000, pp 103-119.

21 Eads CA, Lord RV, Wickramasinghe K, et al. Epigenetic patterns in the progression of esophageal adenocarcinoma. Cancer Res 2001;61:3410-3418.

22 Eads CA, Lord RV, Kurumboor SK, et al. Fields of aberrant CpG island hypermethylation in Barrett's esophagus and associated adenocarcinoma. Cancer Res 2000;60:5021-5026.

23 Ogino S, Kawasaki T, Brahmandam M, et al. Sensitive sequencing method for KRAS mutation detection by Pyrosequencing. J Mol Diagn 2005;7:413-421.

24 Ogino S, Brahmandam M, Cantor M, et al. Distinct molecular features of colorectal carcinoma with signet ring cell component and colorectal carcinoma with mucious component. Mod Pathol 2006;19:59-68.

25 Boland CR, Thibodeau SN, Hamilton SR, et al. A National Cancer Institute Workshop on Microsatellite Instability for cancer detection and familial predisposition: development of international criteria for the determination of microsatellite instability in colorectal cancer. Cancer Res 1998;58:5248-5257.

26 Ogino S, Meyerhardt JA, Cantor M, et al. Molecular alterations in tumors and response to combination chemotherapy with gefitinib for advanced colorectal cancer. Clin Cancer Res 2005;11:6650-6656.

27 Esteller M, Toyota M, Sanchez-Cespedes M, et al. Inactivation of the DNA repair gene O6-methylguanineDNA methyltransferase by promoter hypermethylation is associated with $\mathrm{G}$ to A mutations in K-ras in colorectal tumorigenesis. Cancer Res 2000;60:2368-2371.

28 Esteller M, Risques RA, Toyota M, et al. Promoter hypermethylation of the DNA repair gene $\mathrm{O}(6)-$ methylguanine-DNA methyltransferase is associated with the presence of $\mathrm{G}: \mathrm{C}$ to $\mathrm{A}: \mathrm{T}$ transition mutations in p53 in human colorectal tumorigenesis. Cancer Res 2001;61:4689-4692.

29 Shen L, Kondo Y, Rosner GL, et al. MGMT promoter methylation and the field defect in sporadic colorectal cancer. J Natl Cancer Inst 2005;97:1330-1338.

30 Giovannucci E, Ogino S. DNA methylation, field effects, and colorectal cancer. J Natl Cancer Inst 2005; 97:1317-1319.

31 Yamashita K, Dai T, Dai Y, et al. Genetics supersedes epigenetics in colon cancer phenotype. Cancer Cell 2003;4:121-131.

32 Anacleto C, Leopoldino AM, Rossi B, et al. Colorectal cancer 'methylator phenotype': fact or artifact? Neoplasia 2005;7:331-335.

33 Chan AO-O, Issa J-PJ, Morris JS, et al. Concordant $\mathrm{CpG}$ island methylation in hyperplastic polyposis. Am J Pathol 2002;160:529-536.

34 Frigola J, Sole X, Paz MF, et al. Differential DNA hypermethylation and hypomethylation signatures in colorectal cancer. Hum Mol Genet 2005;14:319-326. 